\title{
THE IMPACT OF BREXIT ON MOTOR INDUSTRY IN UK
}

\author{
Aimin Zhang \\ East China University of Science and Technology, P.R.China \\ Ran An \\ East China University of Science and Technology, P.R.China
}

\begin{abstract}
The paper provides studies review on the effect of English economy after Brexit in June 2016 and an analysis of risks arising in the motor manufacturing industry under the effect of Brexit. The economy of UK is in general experiencing stable growth in the latest years, but from the perspective of trading, sterling, investment and negotiation ability of UK, there will be a large negative impact in the long term after withdrawn from EU. The motor manufacturing industry as a great contributor to the country's economy and a sector with large export and import trading is another angle of view analyzing the effect Brexit has on the whole economy of the United Kingdom. Thus the negotiation and agreement reached in two years is important for both the UK government and EU to determine the further relationship and in order to minimize cost and ensure continued economy growth.
\end{abstract}

Key words: UK, Motor Industry, Brexit

\section{JEL code: F150}

\section{Introduction and Literature Review}

The UK voted to leave the EU by referendum on 23 June, with $51.9 \%$ voting leave and $48.1 \%$ voting to remain. Most recent literatures have a negative view on the economy growth of UK due to uncertainties arising from the aspects of trading with EU, negotiation process, foreign investment, immigration policies etc.

The trade in both goods and services between the UK and EU is very substantial: 306 
billion euros of exports of goods by the EU to the UK, versus 184 billion euros of imports, and thus a large surplus of account of goods alone (data for 2015). In terms of \% shares of GDP, the EU's exports to the UK amount to $2.5 \%$ of GDP, whereas the UK's exports to the EU amount to 7.5\% of its GDP. EU is the largest trade partner of UK. Large trading transactions demonstrate the importance of the relationship between UK and EU which will be negotiated and come out in two years.

Although the position of the United Kingdom is not clear, Cavalier and Bossy (2016) explained that the result will have separate consequences for the EU and the UK. Brexit would be significantly negative for real GDP growth in the UK in the short term, but its impact will be modestly negative elsewhere in Europe and negligible in the rest of the world. While Thomas (2017) stated that, in the aspect of British engagement in European external affairs and development cooperation, its potential impact is considerable with challenges including short-term problems regarding existing legal obligations, looming budget shortfalls and the securing of business continuity as well as the longer-term realignment of EU development policy following the departure of the United Kingdom.

Economist holds the opinion that UK has an obvious disadvantage, for example, it did not participate in trade negotiations for the past 40 years, and currently has very little negotiating capacity. Nonetheless, it needs diplomatic expertise to provide information on the objectives and strategies of its negotiating partners.

There are studies proving that being an EU member brings benefits and estimates on economic losses considering different alternatives to staying an EU member. Baier et al. (2008) examines the effects of EU membership, EFTA membership and EEA membership on international trade between the countries participating in the trade agreements and finds that being a member of EU, EFTA or EEA increases trade by about 75\%. Ottaviano et al. (2014) has found that the cost will be smaller when the UK remains more economically integrated with the EU. Booth et al. (2015) assumes if UK falls back to WTO's MFN tariffs, the loss in UK's GDP will be of $2.2 \%$. Dhingra et al. (2016) states that the short term decline in income of Brexit on UK's trade will lay between $1.3 \%$ to $2.6 \%$ and that the long term effect will raise to $6.3 \%$ 
and $9.5 \%$.

As Cavalier and Bossy (2016) stated, the main problem is uncertainty. Handley and Limão (2013) and Pierce and Schott (2016) highlight the role of trade policy uncertainty in delaying Chinese firms' decisions about exporting to the United States until China's 2001 accession to the WTO. Here, uncertainty about Brexit creates a real option value of delaying decisions about export participation in trade with both the European Union and the rest of the world. UK firms that can export to the rest of the world face similar circumstances to those faced by Chinese firms before WTO accession.

The main economic benefit of leaving the EU would be a lower net contribution to the EU budget. However, considering the hard negotiations faced UK which determine the export and import trades regulations between UK and EU and the huge uncertainty, GDP reduction implied by Brexit is likely to occur but not precisely measured depending on the variables used in the equations and the benefits generated by the long-run trade policies of British authorities.

\section{Motor Vehicle Industry Under the Effect of Brexit}

The motor manufacturing industry is a successful part of the United Kingdom and it has already become one of the largest car producer in the world. Besides, motor vehicle manufacturing industry is a typical import and export sector which will be under great effect of Brexit. Take motor vehicle industry as an example is appropriate and significant.

The total turnover of the motor manufacture is $£ 5.9$ billion in $2016,58.6 \%$ of which is generated by exporting (table 1). The revenue heavily depends on the trading in exporting.

The export and import trading are under positive and negative effects of the fall in the value of the sterling separately. The cost of importing cars will be more expensive, and since the UK motor manufacturing needs a great proportion of importing 
components and assembled vehicles, there is a large adverse effect. Exports on the opposite become more price-competitive while UK still being a member of EU but the sales of cars are likely impacted by the slowdown economy.

Table 1. Turnover and export data for manufacture of motor trades industry, 2010 to 2016

\begin{tabular}{lrrrrrrr}
\hline \multirow{2}{*}{ million } & 2010 & 2011 & 2012 & 2013 & 2014 & 2015 & 2016 \\
\cline { 2 - 8 } turnover & $34,522.1$ & $39,587.2$ & $41,297.4$ & $47,108.5$ & $49,659.3$ & $52,702.4$ & $59,301.1$ \\
export & $17,353.6$ & $22,161.0$ & $21,853.7$ & $26,597.0$ & $28,259.1$ & $29,279.0$ & $34,748.7$ \\
export ratio & $50.27 \%$ & $55.98 \%$ & $52.92 \%$ & $56.46 \%$ & $56.91 \%$ & $55.56 \%$ & $58.60 \%$ \\
\hline
\end{tabular}

According to the lasted figures published by SMMT, 1.7 million cars were built in the UK in 2016, an increase of 8.5\% compared with 2015 and achieved a 17-year output high since 1999.

Production growth was dominantly driven by overseas demand, with more than 1.35 million cars shipped worldwide, increasing by $10.3 \%$ nearly 5 times greater than the domestic appetite growth. Within $78.8 \%$ cars manufactured exported, more than one in two cars are exported to Europe (table 3), the single biggest trading partner, with demand up $7.5 \%$.

Table 2. Car manufacturing in UK 2015-2016

\begin{tabular}{lccc}
\hline & 2015 & 2016 & $\%$ change \\
\cline { 2 - 4 } Home & 359,796 & 368,482 & $2.4 \%$ \\
Export & $1,227,881$ & $1,354,216$ & $10.3 \%$ \\
Total & $1,587,677$ & $1,722,698$ & $8.5 \%$ \\
Export ratio & $77.3 \%$ & $78.8 \%$ & \\
\hline
\end{tabular}

Table 3. Top 5 Export destinations for UK cars

\begin{tabular}{ccccc}
\hline EU & US & China & Turkey & Australia \\
$56 \%$ & $14.5 \%$ & $6.5 \%$ & $3.1 \%$ & $2.5 \%$ \\
\hline
\end{tabular}


The motor manufacturing industry of UK is currently thriving based on the substantial increase in turnover and total value added to the GDP. Besides the multiple factors leading to the success of the industry such as large investment in R\&D ( 2.5 billion), high production quality and engineering excellence, another key factor is that UK is enjoying favorable trading conditions with EU, the most important market. As a membership of EU before Brexit, motor industry could trade freely with all EU countries without any tariff and non-tariff barrier cost and get access to talent from EU with regulatory certainty.

However, there primarily arises three types of risks as a result of withdrawn from EU.

1. Tariff barrier cost

There are 3 possible models for the United Kingdom outside the European Union as alternatives to EU membership published by the government in March 2016:

a. membership of the European Economic Area (EEA), like Norway

b. negotiated bilateral agreement, such as that between the EU and Switzerland, Turkey or Canada

c. World Trade Organization (WTO) membership without any form of special agreement with the EU, like Russia or Brazil

The first element of the Single Market is that there are no internal tariffs on trade within the EU. The tariff-free movements of goods ensure the lower price of English goods to compete with all other European countries on the same basis.

The second element of the Single Market - customs union - means that there are no customs checks on trade within the EU. Such compliance checks add to an exporter's costs and thus create trade barriers. The administrative costs associated with customs are an important barrier to trade.

If the UK-EU trade falls back to WTO terms in an absence of trade deal, the tariff on vehicles will be at $10 \%$ and on average $4.5 \%$ on vehicle components.

As the trade costs rise due to possibly tariff barrier, it increases the cost of production, in other words, it may cause higher prices for customers undermining competitiveness 
of the motor industry in UK. What's more, production in UK becomes less attractive because of the increased shipping cost.

In the aspect of investment in the UK motor industry, decisions are depended on whether the companies' operations and market exposure are based in Europe and overseas or in UK.

Taking BMW as an example, it uses UK factories as a satellite factory focusing on exporting to the EU. However, each car is made up of thousands of components some of which have to cross the English Channel three or four times during production. Remaining locating in UK seems irrational in the terms of tariff cost between UK and the EU. Other car plants in Britain operate with what is known as "just-in-time" (JIT) production may be brought to a production halt if there is any interruption caused by delay at the EU and UK border. The cost of investing is increased in such situation.

On the other hand, EU-based manufacturers such as Ford and Jaguar Land Rover who export components or vehicles to UK with good market exposure will consider invest or expand their factories in UK. Opening new sites in UK to support the substantial operations will offset the import cost reducing the impact of tariff cost.

\section{Non-tariff barrier}

A non-tariff barrier is any measure, other than a customs tariff, that acts as a barrier to international trade, including

a. regulations: Any rules which dictate how a product can be manufactured, handled, or advertised

b. rules of origin: Rules which require proof of which country goods were produced in

c. quotas: Rules that limit the amount of a certain product that can be sold in a market.

After leaving the EU, UK enjoys the freedom not to adhere to certain EU regulations any more, however, the non-tariff cost arises in mentioned aspects will make it harder to trade goods whatever new relationships UK and the EU step in. 
Regulatory standard is a significant non-tariff barrier. If the current level of EU-UK trade is to be maintained, ongoing mutual recognition of regulatory standards may be required. In October 2016, the Prime Minister announced the Government's intention to introduce a Great Repeal Bill. It will repeal the European Communities Act 1972, which makes EU law part of the UK legal system, and will convert existing EU law into domestic law, wherever practical. The aim of the Bill is to ensure a "calm and orderly" exit from the EU. It could be seen as the first step towards regulatory co-operation with the EU.

If the UK signs a free trade agreement but leaves the EU customs union, any goods crossing the border would have to meet rules of origin requirements to prove that they indeed come from the UK, introducing paperwork and non-tariff barriers. Especially automotive sector with an integrated EU supply chain and high levels of both imports and exports, might be unable to comply with the local content requirements contained in the EU's preferential rules of origin. In this scenario, WTO most favored nation tariffs would be imposed, increasing costs and disrupting the UK's place within the EU supply chain.

Non-tariff barrier should be given equal consideration as the tariff barriers. Trade costs of non-tariff barrier are even larger than tariff barrier. Regulatory issues, product standards, banking, access to market and technical barriers are significant to exporters and are experienced by companies trading in other countries. According to HSBC, non-tariff barriers to trade following the UK's exit from the European Union could be equivalent to a tariff of 10 to 15 per cent. The negotiation that UK government is facing includes a complexity of managing the challenge. Failure to continue the application of EU's common customs codes and procedures will make a significant administrative and compliance cost when trading with EU.

\section{Labor issues}

The number of EU citizens living in the UK at the end of 2016 is estimated at 3.35 million. The largest number are workers $(2,002,000)$, compared to pensioners $(223,000)$ and the unemployed $(102,000)$. The number of UK citizens living in EU 27 
countries is substantially less: $1,217,000$, of which 400,000 are pensioners, with remainder being workers and their dependent families, and students (based on ONS population statistics for 2015 and net migration statistics for 2016).

According to the latest figures from Office for National Statistics (ONS), since January to March 2009, the number of non-UK nationals from outside the EU working in the UK has been broadly flat but the number of non-UK nationals from EU countries working in the UK has continued to increase (see figure 1). Till 2016, total EU nationals working in UK has arrived at 2248 thousands almost twice as non-EU nationals at 1242 thousands.

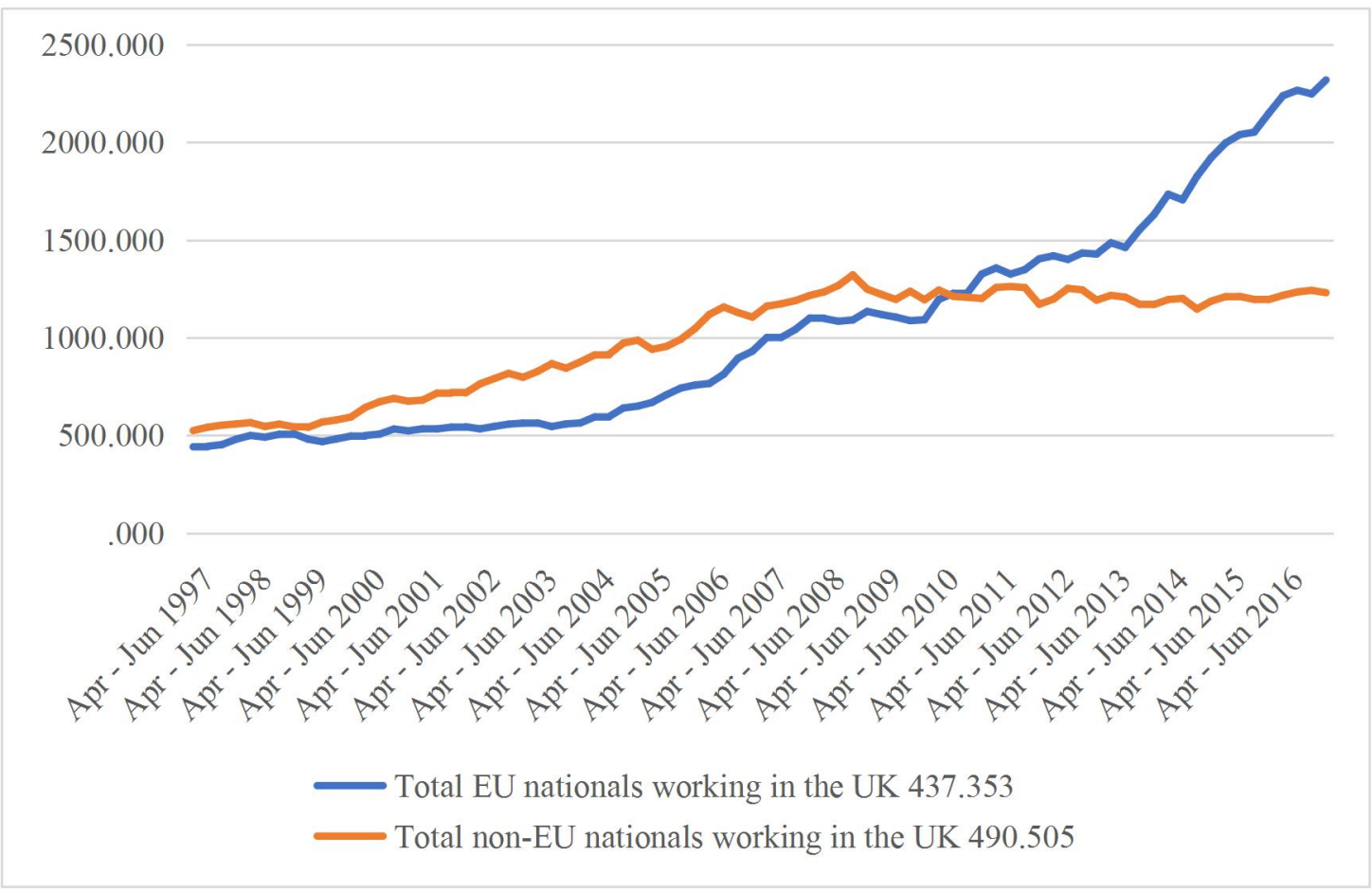

Figure 1. Non-UK nationals working in the UK 1997-2016

According to the figures of SMMT, UK automotive companies of all types and sizes have a significant workforce of non-UK EU workers with an estimation of on average $10 \%$, but some companies over $50 \%$.

Thus the free movement of labor to and from EU is essential to UK's efficiency and flexibility of labor market. Transfers of key staff within the firm may be harder if 
migration controls are put in place. Different regulatory standards can make engineering, R\&D and consultancy services trickier. For UK motor manufacturing industry, any changes in the current position relating to labor movement will create risk losing skilled and experienced workforce leading to a damage to its competitiveness. A new UK approach to immigration must take account of the needs of businesses in the UK. The ability to recruit and move staff to and from the EU is essential to the manufacturing industries.

In summary, motor manufacturing industry relies a lot on the export and import trade worldwide notably with EU. As a major contributor to GDP of UK, motor manufacturing sector under impact of Brexit exposes to three kinds of risks which bring uncertainty to the continued growth. It is likely that all the existing alternatives to EU membership would come with a significant economic cost. They would make it more difficult and expensive to trade with Europe and across the world, and lead to a reduction in foreign investment. It is necessary for the UK government provide continued reassurance in motor trading in the negotiation with EU.

\section{Conclusion}

Brexit with no doubt brings UK economy huge uncertainty. Although it is hard to measure the precise cost leaving EU in the long term since the position of $\mathrm{UK}$ is uncertain before agreement reached, hard negotiations and delaying trade policies show negative view on the economy growth. More evidence come from the analysis of the motor manufacturing sector which exposed most to EU. UK has to decide the relationship from three existing alternatives. However, remaining in the Single market like Norway and Switzerland or trading under WTO rules imply potential tariff, non-tariff barrier cost and arises other labor issues. The cost makes the exporting and importing sectors especially motor manufacturing more expensive and foreign investment less attractive, further leading to negative impact on the whole economy of UK. It is important for the UK government to study the examples of Norway and Switzerland to further benefit from trading with EU, pass new legislations to complete the gap after losing legal force of EU regulations and guarantee the economic and social rights of EU workers in UK. 


\section{References}

Allen, Treb. (2014) "Information Frictions in Trade," Econometrica, November, 82, 2041-2083.

Anderson, James E. and Eric van Wincoop. (2004) "Trade Costs," Journal of Economic Literature, September,42 (3), pp. 691-751.

Arbuthnot Banking Group. (2016) Lea R. Post-Brexit trading options for the UK[J].

Baier, Scott L., Bergstrand, Jeffrey H., Egger, Peter and McLaughlin, Patrick A. (2008) Do Economic Integration Actually Work? Issues In Understanding the Causes of and Consequences of the Growth of Regionalism. The World Economy 31 (5): 461-497.

Booth, Stephen., Howarth, Christopher., Persson, Mats., Ruparel, Raoul and Swidlicki, Pawel. (2015) What if...? The Consequences, challenges and opportunities facing Britain outside EU. Report/Open Europe. London: Open Europe.

Cavalier Bruno, Bossy Fabien. (2016) Is Brexit Painful? Is Brexit Contagious? ODDO Economy, Thursday 30 June.

Cavalier Bruno, Bossy Fabien (2016) Undermined Europe. Criticized Europe Incomplete Europe, ODDO Securities, June.

Dhingra S, Ottaviano G, Sampson T, et al. (2016) The consequences of Brexit for UK trade and living standards, CEP[J].

Dhingra, Swati and Sampson, Thomas. (2016) Life after BREXIT: What are the UK's options outside the European Union. BREXIT 2016, Policy analysis from the Centre for Economic Performance. 1-11.

Hrebenciuc A. (2017) The costs of Brexit for UK economy[J]. Theoretical and Applied Economics, 24(2 (611), Summer): 319-327.

Kohl, T., Brakman, S. and Garretsen, J. (2017) Consequences of Brexit and Options for "Global Britain", CESifo working paper, No. 6648.

Lim, Kevin. (2016) "Firm-to-Firm Trade in Sticky Production Networks," Working paper.

Minford, P. (2015) 'Evaluating European Trading Arrangements', Cardiff Economics Working Paper No. E2015/17.

Ottaviano, Gianmarco I. P., Joao P. Pessoa, Thomas Sampson and John Van Reenen (2014) "The Trade and Welfare Effects of Leaving the European Union," CEP Paper No. CEPPA016.

Sampson, T. (2016) Four principles for the UK Brexit trade negotiations, Center for Economic Performance. 
Thomas Henökl. (2017) How Brexit affects EU External Action: the UK's legacy in European international cooperation[J]. Futures. 